\title{
The Effect of Coenzyme Leakage and Replacement on the Growth and Metabolism of Two Fusobacteria
}

\author{
By R. S. COLES, JUN. \\ Department of Microbiology, College of Medicine and Dentistry of New Jersey, \\ New Jersey Medical School, Newark, New Jersey 07103, U.S.A.
}

(Received 28 June 1974; revised 19 August 1974)

\section{SUMMARY}

Suspensions in water of two species of Fusobacterium leaked several coenzymes when incubated at normal growth temperatures. Chromatography of filtrates from these suspensions revealed the presence of NAD, NADP, FMN, tetrahydrofolic acid and, in one of the two, pyridoxal phosphate. Analyses of some enzymic activities in whole organisms demonstrated deficiencies in coenzymes: glutamate dehydrogenase was virtually inactive in the absence of added NAD; tryptophanase activities were diminished by washing but the extent differed between strains; histidase activity was not decreased by washing or suspension in water or saline. Both lag phase and doubling time increased markedly in severely washed organisms inoculated into fresh medium. Addition of appropriate coenzymes shortened the lag phase for both strains and shortened the doubling time in one.

\section{INTRODUCTION}

Bacteria may leak ultraviolet-absorbing material when treated with certain chemicals or heat (Kenis \& Morita, I968; Brown \& Winsley, 1969; Allwood \& Russell, 1970; Morris \& Russell, I970; Allwood \& Hugo, I971). An Escherichia coli lysine auxotroph also leaks a variety of nucleotide derivatives when grown in medium containing suboptimal concentrations of lysine (Lilly, Clarke \& Meadow, 1963). Commonly, however, living organisms retain vital compounds when incubated at normal growth temperature. The classical exceptions to this are the Rickettsiae which lose vital coenzymes in vitro (Moulder, 1962).

Aqueous suspensions of Fusobacterium polymorphum and $F$. fusiforme leak several coenzymes. Supernatant fluids from suspensions of $F$. polymorphum contained FMN, 5,6,7,8tetrahydrofolic acid (THFA), degradation products from THFA, NAD and NADP. In addition, reducing substances can be washed from the bacteria because growth of washed $F$. polymorphum under semi-anaerobic conditions occurs only when reducing substances are added to the growth medium, whereas unwashed cultures grew well without additional reducing substances (Coles, I973).

Because amino acid metabolism plays an important role in the growth of fusobacteria (Loesche \& Gibbons, 1968; Werner, Neuhaus \& Hussels, 1971), we attempted to correlate coenzyme leakage with ability to maintain tryptophanase, glutamate dehydrogenase and histidase activities under a variety of conditions.

\section{METHODS}

Organisms. Fusobacterium polymorphum (ATCC10953) was obtained from the American Type Culture Collection. Fusobacterium fusiforme was obtained from the Communicable 
Disease Center, U.S. Public Health Service, Atlanta, Georgia, U.S.A. Stock cultures of both organisms were maintained by growing at $37^{\circ} \mathrm{C}$ for $18 \mathrm{~h}$ in Brewers modified thioglycolate medium (Fisher Scientific Co., Fair Lawn, New Jersey, U.S.A.).

Media. Modified Omata's medium (Coles, I968) was used for growth studies on $F$. polymorphum. Fusobacterium fusiforme did not require adenine but did require thymine ( $125 \mathrm{mg} / \mathrm{l})$, folic acid (I $\mathrm{mg} / \mathrm{l}$ ) and nicotinic acid (I mg/l). Therefore, Omata's medium was further modified by omitting adenine and including the required compounds. Screw cap tubes ( $16 \times 150 \mathrm{~mm}$ ) containing $10 \mathrm{ml}$ medium were autoclaved ( $15 \mathrm{~min}$ at $\mathrm{I} 2 \mathrm{I}{ }^{\circ} \mathrm{C}$ ), flushed with sterile $5 \% \mathrm{CO}_{2}+95 \% \mathrm{~N}_{2}$, cooled, inoculated with about $\mathrm{I} \times \mathrm{IO}^{6}$ organisms, and again flushed with $5 \% \mathrm{CO}_{2}+95 \% \mathrm{~N}_{2}$. Coenzymes of nucleotides, where used, were filter sterilized and added immediately before inoculation. Sterile $\mathrm{H}_{2}$ was bubbled through all NAD, NADP and FMN solutions for $3 \mathrm{~min}$ immediately before their addition to the growth media. Coenzymes and nucleotides were added at a concentration of $100 \mu \mathrm{g} /$ tube. Cultures were incubated anaerobically at $37^{\circ} \mathrm{C}$. Growth was measured by turbidity increase at $660 \mathrm{~nm}$ using a Coleman Model 44 Spectrophotometer (Ace Scientific Supply Co., Linden, New Jersey, U.S.A.).

Organisms used for studies on amino acid degradation were grown similarly in the medium used for the growth studies, with the following changes. For bacteria induced for tryptophanase (EC.4.2.I.-) the medium contained L-tryptophan (200 mg/l). For the histidase (L-histidine ammonia lyase, EC. 4.3 . I .3) study, the tryptophan concentration was decreased to $50 \mathrm{mg} / \mathrm{l}$ and $\mathrm{L}$-histidine $(200 \mathrm{mg} / \mathrm{l})$ was added to the medium. For the glutamate dehydrogenase [L-glutamate:NAD oxido-reductase (deaminating), EC. I.4.I.2], the tryptophan concentration was $50 \mathrm{mg} / \mathrm{l}$ and no histidine or glutamic acid was added beyond the amount contained in the Casamino acids.

Analysis of enzyme activity. For each assay, one half of the appropriate culture was washed four times with equal volumes of water at $4{ }^{\circ} \mathrm{C}$. The washed bacteria were suspended to a protein concentration of approximately $\mathrm{I}$ to $\mathrm{I} \cdot 5 \mathrm{mg} / \mathrm{ml}$. The other half of the culture was centrifuged and resuspended in distilled water, without further washing, to the same concentration. Both washed and unwashed organisms were assayed for the appropriate enzymic activity.

For determination of tryptophanase activity the method of Freundlich \& Lichstein (1960) was used. Glutamate dehydrogenase activity was determined by following the release of ammonium ion from glutamic acid using Nessler's reagent (Umbreit, Burris \& Stauffer, 1957). Tubes for this assay contained $200 \mu \mathrm{mol}$ potassium phosphate buffer $\mathrm{pH} 7 \cdot 5$; I00 $\mu$ mol sodium glutamate $\mathrm{pH} \mathrm{7.5}$; washed or unwashed bacteria corresponding to $200 \mu \mathrm{g}$ protein; $20 \mu \mathrm{g}$ NAD,"where specified; and water to a final volume of $2 \mathrm{ml}$. The reaction was stopped by addition of $0.2 \mathrm{ml}$ of $10 \%(\mathrm{w} / \mathrm{v})$ TCA. All assays were performed at $37{ }^{\circ} \mathrm{C}$. Protein was determined by the method of Lowry, Rosebrough, Farr \& Randall (I95X).

The method of Cornell \& Lien (1970) was used to determine histidase activity, except that $\mathrm{Mg}^{2+}$ was substituted for the $\mathrm{Zn}^{2+}$ because $\mathrm{Zn}^{2+}$ ions were found to inhibit histidase in both organisms whereas $\mathrm{Mg}^{2+}$ stimulated the reactions.

Preparation and chromatographic analysis of filtrates from aqueous suspensions. A bacterial culture (4 1) grown anaerobically at $37^{\circ} \mathrm{C}$ for $\mathrm{I} 8 \mathrm{~h}$ (mid-exponential phase) was centrifuged at $20000 \mathrm{~g}$. The pellet and containers were rinsed with distilled water at $4{ }^{\circ} \mathrm{C}$. The bacteria were suspended in distilled water to a concentration of $5 \times 10^{9}$ organisms $/ \mathrm{ml}$ and incubated at $37^{\circ} \mathrm{C}$ in stoppered flasks with no more than $5 \mathrm{~mm}$ air space. They were gently shaken for $3 \mathrm{~h}$. The suspensions were centrifuged at $20000 \mathrm{~g}$ and the supernatant fluids filtered through a sterile $0.2 \mu \mathrm{m}$ membrane filter (Ace). The filtrates were then lyophilized and reconstituted to 


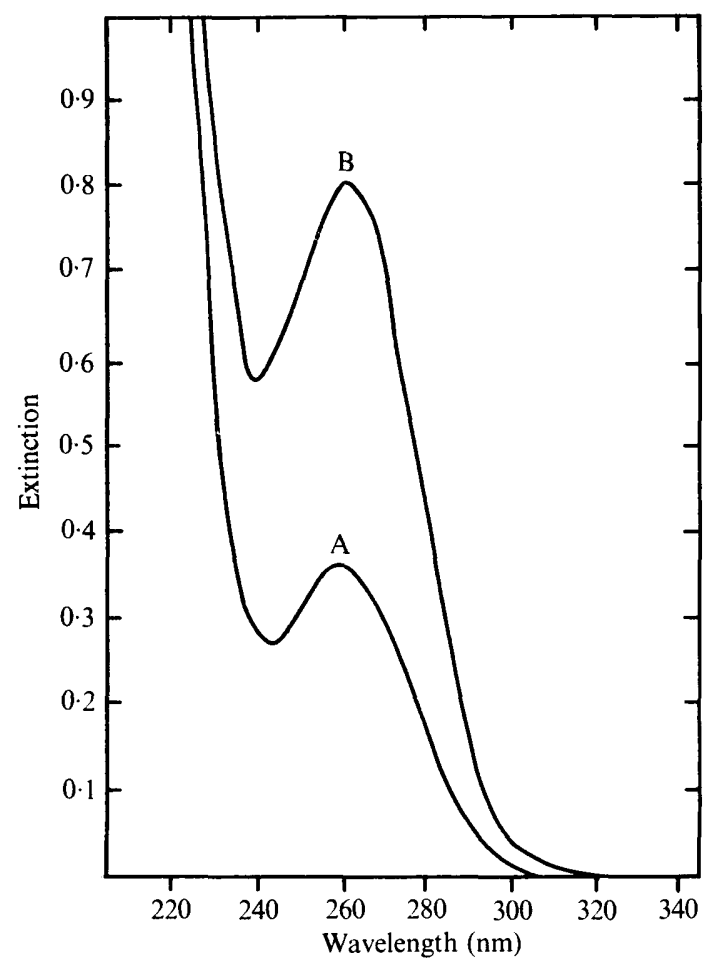

Fig. I. Absorption spectra of filtrates from Fusobacterium polymorphum suspensions. Organisms were harvested from the mid-exponential phase of growth, centrifuged and resuspended in water (zero time), then incubated at $37^{\circ} \mathrm{C}$ for $3 \mathrm{~h}$. A, zero time filtrate; $\mathrm{B}, 3 \mathrm{~h}$ filtrate.

I/50 their original volume. The filtrates were frozen and kept in the dark for chromatographic analysis and for use as supplements for both enzyme assays and the growth experiments. Identification of coenzymes in the filtrates was made by one and two dimensional thin-layer chromatography on Bakerflex silica gel IB-F sheets (J. T. Baker Chemical Co., Phillipsburg, New Jersey, U.S.A.) The solvent systems used were ammonia-methanol $(3: 7, v / v)$ as used by Nuttall \& Bush (197I), and water-saturated butanol. After development (the solvent migration was $150 \mathrm{~mm}$ at $25^{\circ} \mathrm{C}$ ), the sheets were air-dried and examined under $260 \mathrm{~nm}$ and $366 \mathrm{~nm}$ u.v. light.

\section{RESULTS}

Supernatant fluids from aqueous suspensions of both organisms absorbed u.v. light. Without decrease in turbidity of the suspensions, the u.v. absorption increased during $3 \mathrm{~h}$ of incubation at $37^{\circ} \mathrm{C}$ (Fig. I). The absorption peak was sharp at $260 \mathrm{~nm}$, indicating that there was no large release of protein, as would be expected from lysis.

Chromatography of the concentrated filtrates demonstrated several u.v.-absorbing and fluorescent compounds. Of those, NAD, NADP and FMN were readily identifiable by $R_{F}$, absorption and fluorescent characteristics in filtrates from both organisms. No pyridoxal phosphate was detected in the $F$. polymorphum filtrates, but it was readily detected in the filtrate from the $F$. fusiforme suspension. Two other spots were noted on all chromatograms. Both showed bright blue fluorescence when excited at $366 \mathrm{~nm}$. One was identical in $R_{F}$ and 
Table I. Tryptophanase activity of $F$. polymorphum and $F$. fusiforme

Tubes contained L-tryptophan $\mathrm{pH} 8(\mathrm{I} O \mu \mathrm{mol})$ and phosphate buffer $\mathrm{pH} 8(200 \mu \mathrm{mol})$, plus additions of pyridoxal phosphate or concentrated filtrates or concentrated washings where indicated, and bacteria and water to $2 \mathrm{ml}$. The reaction was stopped after $\mathrm{I} h$ incubation at $37^{\circ} \mathrm{C}$ by rapid freezing at $-70^{\circ} \mathrm{C}$. Tubes were kept at $-70^{\circ} \mathrm{C}$ until assayed for indole.

Activity (nmol indole produced/mg protein/h)

\begin{tabular}{|c|c|c|c|c|c|c|}
\hline $\begin{array}{l}\text { Age of culture } \\
\text { (h) }\end{array}$ & $\begin{array}{l}\text { No } \\
\text { additions }\end{array}$ & $\begin{array}{l}\text { Pyridoxal } \\
\text { phosphate* }^{*}\end{array}$ & $\begin{array}{c}\text { +Conc. } \\
\text { washings } \dagger\end{array}$ & $\begin{array}{l}\text { No } \\
\text { additions }\end{array}$ & $\begin{array}{l}\text { Pyridoxal } \\
\text { phosphate* }\end{array}$ & $\begin{array}{c}\text { +Conc. } \\
\text { washings } t\end{array}$ \\
\hline \multicolumn{7}{|l|}{. polymorphum } \\
\hline $\begin{array}{l}42 \text { (late exponential } \\
\text { phase) }\end{array}$ & 117 & I 50 & I IO & I I9 & 1I5 & I I 3 \\
\hline 60 (stationary phase) & $25 \mathrm{I}$ & 294 & 254 & 122 & 254 & 197 \\
\hline \multirow[t]{2}{*}{$\begin{array}{l}90 \text { (late stationary } \\
\text { phase) }\end{array}$} & 30 & 244 & 170 & 13 & 200 & 168 \\
\hline & & & $\begin{array}{l}+ \text { Conc. } \\
\text { filtrate }\end{array}$ & & & $\begin{array}{l}+ \text { Conc. } \\
\text { filtratet }\end{array}$ \\
\hline \multicolumn{7}{|l|}{ fusiforme } \\
\hline $\begin{array}{l}\text { 2I (early exponential } \\
\text { phase) }\end{array}$ & 33 & 100 & 89 & 5 & I 12 & IO4 \\
\hline $\begin{array}{l}48 \text { (late exponential } \\
\text { phase) }\end{array}$ & 41 & 180 & I 63 & I I & 107 & 98 \\
\hline 96 (late stationary phase) & 70 & 190 & 165 & 47 & 236 & 180 \\
\hline
\end{tabular}

fluorescence with tetrahydrofolic acid. The other was identical with tetrahydrofolate which had been exposed to air for $24 \mathrm{~h}$ or reacted with $\mathrm{H}_{2} \mathrm{O}_{2}$ for 5 min.

The enzymic activities tested correlate well with the coenzymes detected in the filtrates. For instance, $F$. polymorphum was able to maintain tryptophanase activity of both washed and unwashed suspensions until it reached the stationary phase (Table $I$ ). This is in agreement with the finding that no pyridoxal phosphate was detected in the filtrates from suspensions of mid-exponential phase bacteria. At about $24 \mathrm{~h}$ after the stationary phase was reached, however, even the unwashed bacteria lost tryptophanase activity. In all cases where activity was lost, it could be restored by the addition of pyridoxal phosphate to the reaction mixture. The activity of the late stationary phase organisms could also be restored partially by addition of concentrated washing from these late stationary phase bacteria (Table I).

Fusobacterium fusiforme, however, required exogenous pyridoxal phosphate for maximum tryptophanase activity under all conditions tested (Table I). Unwashed organisms from all stages of growth were stimulated three- to fourfold in the assay by coenzyme addition. Washing of the suspensions further decreased the unstimulated activity. Coenzyme additions to the washed bacteria restored the activity to the levels obtained using unwashed organisms with added coenzyme. Further, the addition of concentrated filtrates from suspensions of F. fusiforme restored tryptophanase activity. Pyridoxine, pyridoxamine, pyridoxal and pyridoxamine phosphate were all unable to restore tryptophanase activity in either organism. The stimulation of tryptophanase in whole bacteria by pyridoxal phosphate suggests an 
Table 2. Glutamate dehydrogenase activity of F. polymorphum and F. fusiforme.

Tubes contained L-glutamate pH 7.5 (100 $\mu \mathrm{mol})$ and phosphate buffer pH $7.5(200 \mu \mathrm{mol})$, plus additions of NAD or concentrated filtrates where indicated, and cells and water to $2 \mathrm{ml}$. The reaction was stopped after $\mathrm{I} h$ incubation at $37^{\circ} \mathrm{C}$ by addition of $0.2 \mathrm{ml}$ of $10 \%(\mathrm{w} / \mathrm{v})$ trichloroacetic acid.

Activity ( $\mu \mathrm{mol} \mathrm{NH}$ produced/mg protein $/ \mathrm{h}$ )

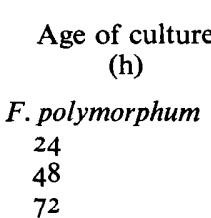

F. fusiforme

24
48
72

$\overbrace{\begin{array}{c}\text { No } \\ \text { additions }\end{array}+\text { NAD* }^{+ \text {Conc. }} \text { filtrate }}^{\begin{array}{c}\text { No } \\ \text { additions }\end{array}+\mathrm{NAD}^{*} \begin{array}{c}+ \text { Conc. } \\ \text { filtrate }\end{array}}$

$\begin{array}{rrrrrr}1 & 6 & 5 & 0 & 4 & 2 \\ 0 & 15 & 10 & 0 & 11 & 8 \\ 0 & 26 & \text { II } & 0 & 25 & \text { II }\end{array}$

$\begin{array}{llllll}0.4 & 3 & 2 & 0.5 & 3 & 2 \\ \mathrm{I} & 4 & 4 & 0 & 3 & 3 \\ 0.6 & 4 & 4 & 0 & 4 & 3\end{array}$

* Added to a final concentration of $10 \mu \mathrm{g} / \mathrm{ml}$. All values have appropriate zero time values subtracted. $\dagger$ Concentrated $(\times 50)$ filtrate from either organism $(0 \cdot 1 \mathrm{ml} /$ tube $)$.

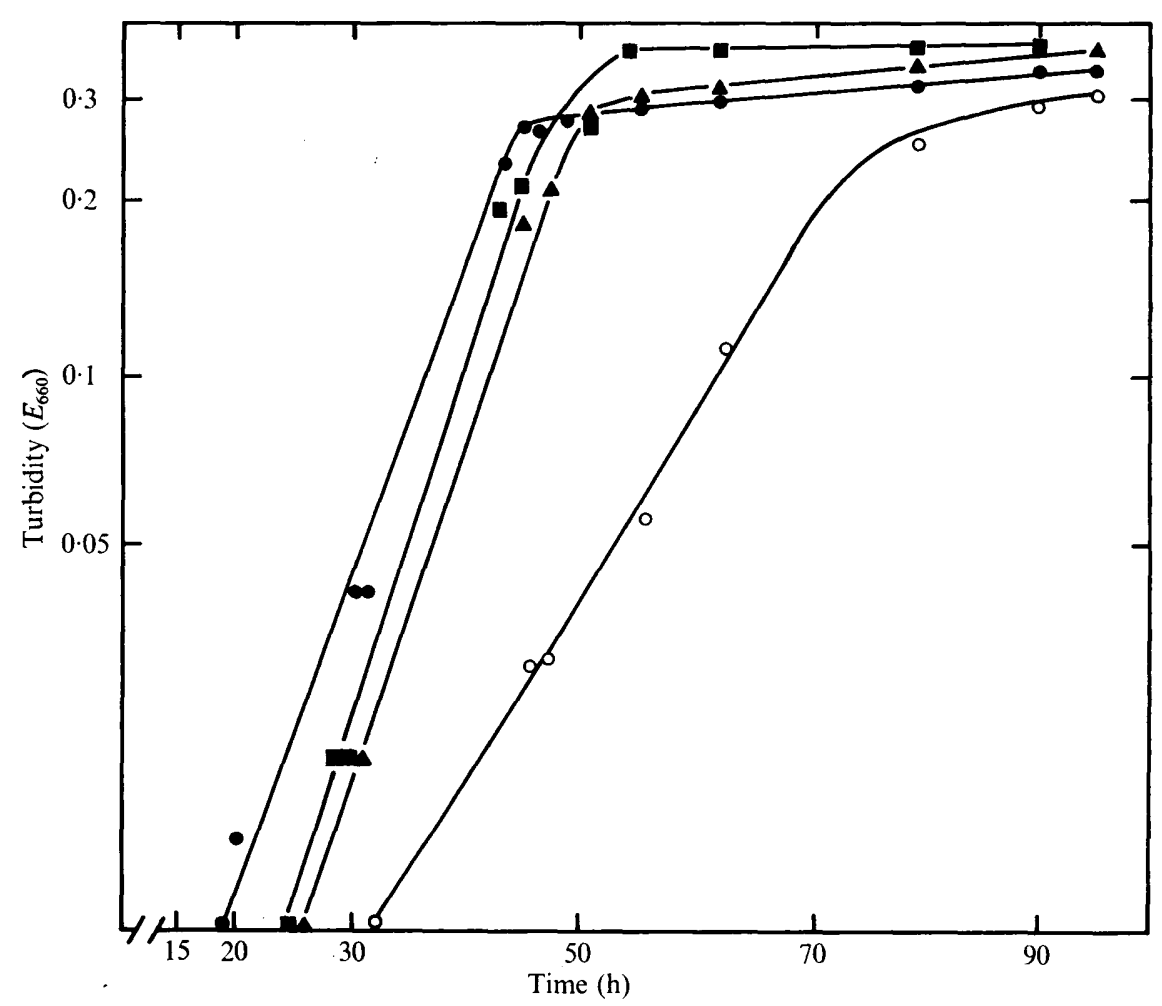

Fig. 2. Effect of cof actors and AMP on growth of washed $F$. polymorphum. Unwashed control; $\boldsymbol{\Delta}$, washed bacteria with concentrated filtrate $(0.1 \mathrm{ml} /$ tube); $\boldsymbol{\square}$, washed bacteria with known additions (Io $\mu \mathrm{g}$ each of NAD, NADP, FMN and AMP $/ \mathrm{ml}$ medium); $O$, washed organisms, no addition. Organisms were harvested during the mid-exponential phase of growth and suspended in water $\left(4^{\circ} \mathrm{C}\right)$. The unwashed control was inoculated into fresh medium. The rest of the suspension was washed 4 times in water $\left(4^{\circ} \mathrm{C}\right)$ and inoculated. All tubes were inoculated with $\mathrm{I} \times 10^{5}$ organisms $/ \mathrm{ml}$. 


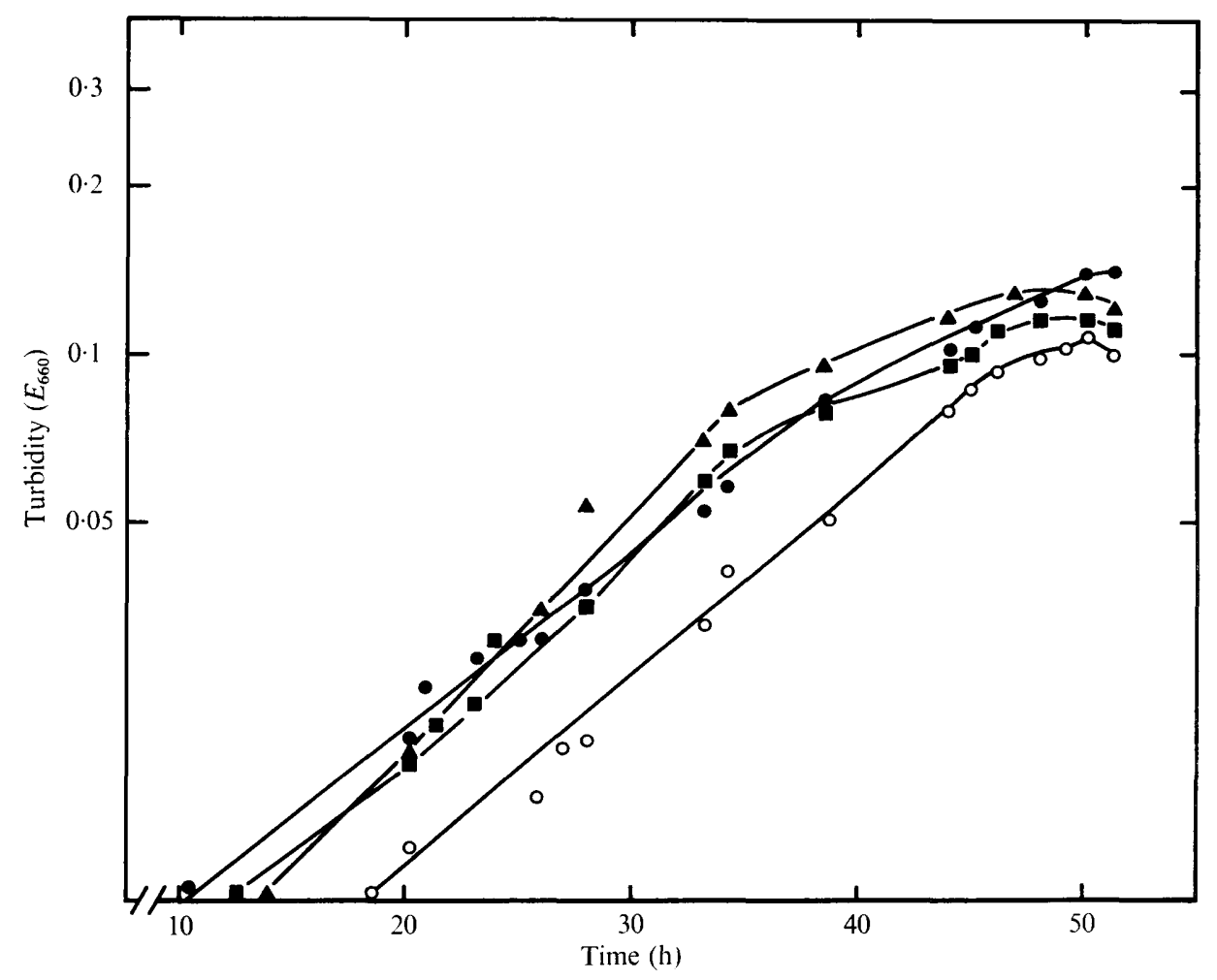

Fig. 3. Effect of cofactors and AMP on growth of washed $F$. fusiforme. Unwashed control; $\boldsymbol{\Delta}$, washed bacteria with concentrated filtrate from $F$. fusiforme resting suspension ( $0.1 \mathrm{ml}$ per tube); $\square$, washed bacteria with known additions (Io $\mu \mathrm{g}$ each of NAD, NADP, FMN, AMP and pyridoxal phosphate $/ \mathrm{ml}$ medium); $O$, washed organisms, no additions. Organisms were harvested during the mid-exponential phase of growth and suspended in water $\left(4^{\circ} \mathrm{C}\right)$. The unwashed control was inoculated into fresh medium. The rest of the suspension was washed 4 times in water $\left(4{ }^{\circ} \mathrm{C}\right)$ and inoculated. All tubes were inoculated with $1 \times 10^{5}$ organisms $/ \mathrm{ml}$.

unusual membrane permeability in these fusobacteria since phosphorylated compounds are not easily taken up by bacteria.

The presence of NAD in all filtrates of both organisms suggested that NAD-requiring enzymes might show suboptimal activity. Accordingly, the glutamate dehydrogenase activity of each organism was examined, and was found to require exogenous NAD for maximum activity (Table 2 ). This requirement was seen in washed and unwashed organisms from all stages of growth. Also, the concentrated filtrates used for chromatography from both organisms enhanced the glutamate dehydrogenase activity for each organism.

Although exogenous reducing substances are required for growth of washed $F$. polymorphum under semi-anaerobic conditions (Coles, 1973), leakage of reduced glutathione (GSH) was not reflected by an appreciable decrease in histidase activity for either organism at any stage of growth.

To determine the effects of coenzyme leakage on growth of the organisms, 4 times washed and unwashed bacteria were inoculated ( $10^{6}$ organisms/ $/ 10 \mathrm{ml}$ medium) and incubated anaerobically with and without various coenzymes. Both washed and unwashed inocula of $F$. polymorphum grew in the unsupplemented medium (Fig. 2). Washing, however, nearly 
doubled the lag phase (from $\mathrm{I} 8 \mathrm{~h}$ for the unwashed culture to $32 \mathrm{~h}$ for the washed) and increased the doubling time from 5.5 to $9.5 \mathrm{~h}$.

Addition of coenzymes, or the concentrated filtrates used for chromatographic analysis and as supplements for the enzyme assays, shortened both the lag and the doubling time. Addition of single compounds of the mixture or omission of any of the compounds from the mixture decreased the growth stimulation.

The results of growth studies with $F$. fusiforme (Fig. 3) were quite different from those with $F$. polymorphum. While washing increased the lag from 10 to $18 \mathrm{~h}$, the doubling time was the same for both washed and unwashed inocula. The addition of sterile concentrated filtrates to media inoculated with washed bacteria shortened the lag phase to approximately $13 \mathrm{~h}$ and also decreased the doubling time to less than that obtained with unsupplemented medium inoculated with washed or unwashed bacteria. The concentrated filtrate from $F$. polymorphum did not show this effect on $F$. fusiforme unless pyridoxal phosphate was added with it. The addition of the known cofactor mixture also decreased the lag but only slightly decreased the doubling time. As with $F$. polymorphum, addition of single supplements to the medium or omission of one of the compounds from the complete mixture resulted in little stimulation of growth. One difficulty with the growth studies on $F$. fusiforme was that the cultures often exhibited a logarithmic decrease in turbidity at about $50 \mathrm{~h}$ (the beginnings of which can be seen in Fig. 3). This decrease remains unexplained; however, we have detected the release of bacteriophage from mitomycin C-treated cultures of this organism. We are currently investigating the possibility that spontaneous induction of this phage caused the sudden drop in culture turbidity.

Several other compounds not seen in chromatograms of filtrates were tested for growth stimulation. These include GSH, several nucleotides, thiamin pyrophosphate, tetrahydrofolate, dihydrofolate, methyltetrahydrofolate and FAD. Of these, only AMP, when added to the coenzyme mixtures, was stimulatory for both organisms. Preliminary evidence indicates that AMP stimulates glucose utilization in whole $F$. polymorphum organisms.

\section{DISCUSSION}

Suspensions of $F$. polymorphum and $F$. fusiforme leak several coenzymes under various conditions. The loss is reflected in both the level of certain enzymic activities and the pattern of growth in semisynthetic medium. The variation in leakage rates depended on both the species and the coenzyme studied.

Histidase activity did not show appreciable decline at any stage of growth by washing in either organism. Purified rat liver histidase also retains considerable activity unless treated with EDTA for $\mathrm{I} 7 \mathrm{~h}$ (Cornell \& Lien, 1970). It is therefore likely that the cofactors, GSH and $\mathrm{Mg}^{2+}$, are bound tightly to the enzyme and would not be washed from the whole organisms by water. Thus, reducing substances which influence growth can be washed from F. polymorphum (Coles, 1973) without affecting the histidase activity.

The intent of the growth studies was not to demonstrate obligatory growth requirements but rather to show that, when available (as in damaged host tissues), certain coenzymes or other compounds stimulated growth. Since, however, growth is the sum total of all vital processes, it is likely that such stimulation would be seen only when all the deficient factors are present. This was true for both organisms examined. The bacteria must be able to synthesize the factors studied, otherwise they would not grow in the medium used. They are also capable of utilizing exogenous supplies of preformed NAD, NADP, FMN, AMP and, in the case of $F$. fusiforme, 'pyridoxal phosphate during growth. An example of the stimulation 
of fusobacteria by damage to host tissue has been presented by Kaufman et al. (1972), who demonstrated that the pathogenicity of $F$. fusiforme was enhanced by co-injection of enzymically active extracts of Bacteroides melaninogenicus. Heated extracts without proteolytic activity were unable to enhance the lesions caused by the fusobacteria.

These data help to explain two phenomena noted for the growth and behaviour of fusobacteria. Difficulty in creating a synthetic medium for growth of washed bacteria or definition of growth requirements of fusobacteria have been encountered (Omata, I953, I959; Coles, I968; Loesche \& Gibbons, I968; Hadi \& Russell, 1970). Loss of NAD and pyridoxal phosphate by the organisms may explain why Hadi \& Russell (1970) found that nicotinic acid and pyridoxine stimulated growth of Fusobacterium nucleatum.

The leakage of coenzymes from fusobacteria may also play a role in the apparent synergism seen between fusobacteria and species of oral Borrelia in acute ulcerative gingivitis. The oral Borrelia require unidentified growth factors (Nevin \& Hampp, 1959) which could be supplied by materials leaked from fusobacteria (especially in localized ulcers enclosed by a pseudomembrane). Conversely, it is also possible for Borrelia or damaged tissue to supply fusobacteria with the coenzymes which they require for maximum activity.

It is also important to determine which coenzymes leak from other fusobacteria. Coenzyme leakage varies not only with the species tested but also with the condition of the organism. Thus, synergistic effects noted with various borrelia would depend on the Fusobacterium used, its phase of growth and the possible requirements of the strain of Borrelia present in the lesion. The reason why Nevin, Hampp \& Duey (1960) failed to demonstrate stimulation of Borrelia growth by fusobacteria may well have been related to the species and condition of the fusobacteria used.

This project was supported, in part, by grant No. 5-RoI AI 09433-03 from the National Institute of Allergy and Infectious Diseases. The excellent technical assistance of Mr R. J. Kaufman is gratefully acknowledged.

\section{REFERENCES}

Allwood, M. C. \& Hugo, W. B. (197I). The leakage of cations and amino acids from Staphylococcus aureus exposed to moist heat, phenol and dinitrophenol. Journal of Applied Bacteriology 34, 369-375.

Allwood, M. C. \& Russell, A. D. (1970). Influence of ionic and nonionic materials on thermally-induced ribonucleic acid degradation and leakage in Staphylococcus aureus. Journal of Pharmaceutical Sciences $59,180-183$.

Brown, M. R. W. \& Winstey, B. E. (1969). Effect of polysorbate 80 on cell leakage and viability of Pseudomonas aeruginosa exposed to rapid changes of $\mathrm{pH}$, temperature and tonicity. Journal of General Microbiology 56, 99-107.

Coles, R. S. (1968). Some growth factors for Fusobacterium polymorphum. Journal of Bacteriology $\mathbf{9 6}$, 2 I $83-2184$.

Coles, R. S. (1973). The effect of glutathione on the growth of Fusobacterium polymorphum. Journal of General Microbiology 75, 75-81.

Cornell, N. W. \& Lien, L. L. (1970). Roles of zinc and glutathione in histidase activity. Physiological Chemistry and Physics 2, 523-535.

Freundlich, M. \& Lichstein, H. C. (I960). Inhibitory effect of glucose on tryptophanase. Journal of Bacteriology 80, 633-638.

HAdI, A. W. \& Russell, C. (1970). Vitamin, purine and pyrimidine requirements of oral fusiforms. Journal of General Microbiology 64, $24 \mathrm{I}-245$.

Kaufman, E. J., Mashimo, P. A., Hausman, E., Hanks, C. T. \& Ellison, S. A. (1972). Fusobacterial infection: enhancement by cell free extracts of Bacteriodes melaninogenicus possessing collagenolytic activity. Archives of Oral Biology 17, 577-580.

KENIS, P. R. \& MORITA, R. Y. (1968). Thermally induced leakage of cellular material and viability in Vibrio marinus, a psychrophilic marine bacterium. Canadian Journal of Microbiology 14, I239-1 244. 
Lilly, M. D., Clarke, P. \& Meadow, P. (1963). The accumulation of nucleotides by Escherichia coli strain 26-26. Journal of General Microbiology 32, 103-1 16.

Loesche, W. J. \& GrbBons, R. J. (I968). Amino acid fermentation by Fusobacterium nucleatum. Archives of Oral Biology 13, 19I-20I.

Lowry, O. H., Rosebrough, A. L., Farr, A. L. \& Randall, R. J. (195I). Protein measurement with the Folin phenol reagent. Journal of Biological Chemistry 193, 265-275.

Morris, A. \& Russell, A. D. (1970). Novobiocin-induced leakage of intracellular substances from Escherichia coli. Microbios 2, 35-4I.

Moulder, J. W. (1962). The Biochemistry of Intracellular Parasitism. Chicago: University of Chicago Press.

Nevin, T. A. \& Hampp, E. G. (1959). Partially defined medium for the cultivation of Borrelia vincentii. Journal of Bacteriology 78, 263-266.

Nevin, T. A., Hampp, E. G. \& Duey, B. V. (1960). Interaction between Borrelia vincentii and an oral diphtheroid. Journal of Bacteriology 8o, 783-786.

NuTTALL, R. T. \& BUSH, B. (197I). The detection of ten components of a multi-vitamin preparation by chromatographic methods. Analyst 96, 875-878.

Omata, R. R. (1953). Studies on the nutritional requirements of the fusobacteria. I. An active principle present in yeast extract. Journal of Bacteriology 65, 326-329.

Oмata, R. R. (1959). Studies on the nutritional requirements of the fusobacteria. II. Requirements for pantothenate and purines. Journal of Bacteriology 77, 35-37.

Umbreit, W. W., Burris, R. H. \& Stauffer, J. F. (1957). Manometric Techniques, 3rd edn, p. I38. Minneapolis: Burgess Publishing.

Werner, H., Neuhaus, F. \& Hussels, H. (1971). A biochemical study of fusiform anaerobes. Medical Microbiology and Immunology 157, I0-16. 